\title{
Understanding the Electoral Rise of the Five Star Movement in Italy
}

\author{
Nicola MagGini*
}

\begin{abstract}
The economic crisis, the fall of the Berlusconi government and the birth of the technocratic government led by Mario Monti have produced several changes in the Italian political system. Certainly, one of the most important innovations in the context of Italian politics has been the emergence of the Five Star Movement. Such a new party has achieved spectacular overnight success in several elections at sub-national level, and now it is the most voted party in the 2013 national elections. The Five Star Movement combines antiestablishment rhetoric with demands for political reform. The article analyses the electoral growth of the Five Star Movement using both aggregate data and individual data from "Osservatorio Politico CISE" (i.e. cross-section and panel surveys conducted from November 2011 to March 2013). In particular, the author investigates whether the profile of the supporters of the Five Star Movement has changed over time, both from a political and a social standpoint. Finally, the author analyses what factors influence the electoral choice for the Five Star Movement, also from a longitudinal perspective.
\end{abstract}

Key words: Five Star Movement; 2013 Italian political elections; voting behaviour; multilevel panel analysis

DOI: 10.5817/PC2014-1-37

\section{The Background and the Electoral Success of the Five Star Movement in the 2013 Political Elections}

The Five Star Movement (M5S) led by the former comedian Beppe Grillo has become one of the most important political actors of the "new transition" that started in Italian politics with the end of the Berlusconi government in November 2011 (Ceccarini et al. 2012). The goal of the current research is to find out the factors which have a greater impact on the propensity to vote for the M5S, also from a longitudinal perspective.

The M5S has been defined as "a strange animal... in the zoo of Italian politics" (Corbetta 2013: 197). According to Corbetta (2013) it shows most of the traits of populist parties but its use of the web puts it in a different category. The M5S has been compared to a bus (Bordignon

\footnotetext{
${ }^{*}$ Dipartimento di Scienze Politiche e Sociali, University of Florence, via delle Pandette, 21-50127 Firenze,nicolamaggini@libero.it
} 
and Ceccarini 2012). Everybody can find something appealing in its programme that crosscuts the traditional political spectrum based on the left-right distinction. The anti-establishment stand of the movement is what keeps everything together. The M5S combines this anti-establishment rhetoric with demands for political reform, transparency and new ways of 'doing politics'.

Several factors enabled the M5S to become a relevant political actor: The ongoing de-structuring of the Italian party system that accelerated significantly in 2011 (Bosco and McDonnell 2012); the consequences of the global economic crisis and the arena offered to the new party by some local elections (Biorcio and Natale 2013; Bordignon and Ceccarini 2013a).

The financial and economic crisis accelerated the end of the Berlusconi government and the formation of Monti's technocratic government. The latter was supported by an anomalous 'grand coalition' (PdL, PD and UdC). These events contributed, indirectly, to the creation of favourable conditions for the success of M5S. Indeed, uncertainty about the future and the demand for social protection clashed with the austerity measures carried out by the Monti cabinet, reinforcing the anti-party and anti-politics sentiment (Biorcio 2013). Distrust toward parties was also strengthened by judicial inquiries on political corruption, which affected all the parties.

The local elections held in May 2012 were a success for the M5S: The new party managed, for the first time, to have four mayors elected (the most important was Federico Pizzarotti, in Parma). The success in local elections in May 2012 came after the good performance of the 2010 regional elections and, above all, before the electoral success obtained in the regional elections held in Sicily on 28 October 2012 when the M5S turned out to be the largest party on the island, although it was not able to win the governorship.

On 21 December 2012, Mario Monti resigned. Elections were set for 24 and 25 February 2013. Their outcome was a surprise and threw Italy into a difficult and uncertain situation as no clear winner emerged (De Sio et al. 2013). In this election, the biggest surprise of all was the astonishing success of the M5S. Without including the foreign constituency, M5S obtained $25.6 \%$ (obtaining a little more than 8.5 million votes) in the Chamber making it the largest party in the country. For a new party competing for the first time in a national election it is an impressive feat: Never in the history of the Republic after the elections of 1946, had a new party obtained a similar percentage at its first political elections. Not even Berlusconi in 1994 with its Forza Italia achieved such a success. As can be seen in Figure 1, it is the leading party in almost half of the provinces ( 50 out of 109) and it is the only one with a truly national base, registering peaks in Sicily (33.5\%), in the Marche and in Liguria (32.1\%).

The success of the Grillo movement certainly occurred at the detriment of the other main parties. Indeed, the analysis of vote shifts ${ }^{1}$ in major cities proves that it drew its support from across the entire political spectrum. Table 1 shows the percentage of voters who changed their vote to the M5S in 2013 with respect to 2008. In the North a noteworthy share of former Northern League (LN) voters shifted to the M5S (e.g. 50\% in Treviso, $46 \%$ in Monza). But in Monza itself $45 \%$ of voters of the radical left in 2008 and $59 \%$ of IdV ${ }^{2}$ voters chose the M5S in 2013. The PD and the PdL also contributed to the success of the M5S. For both parties this seems to be true more in the Centre and in the South than in the North. 
Figure 1: The party with the most votes by province (in parentheses the number of provinces), Chamber of Deputies, \%

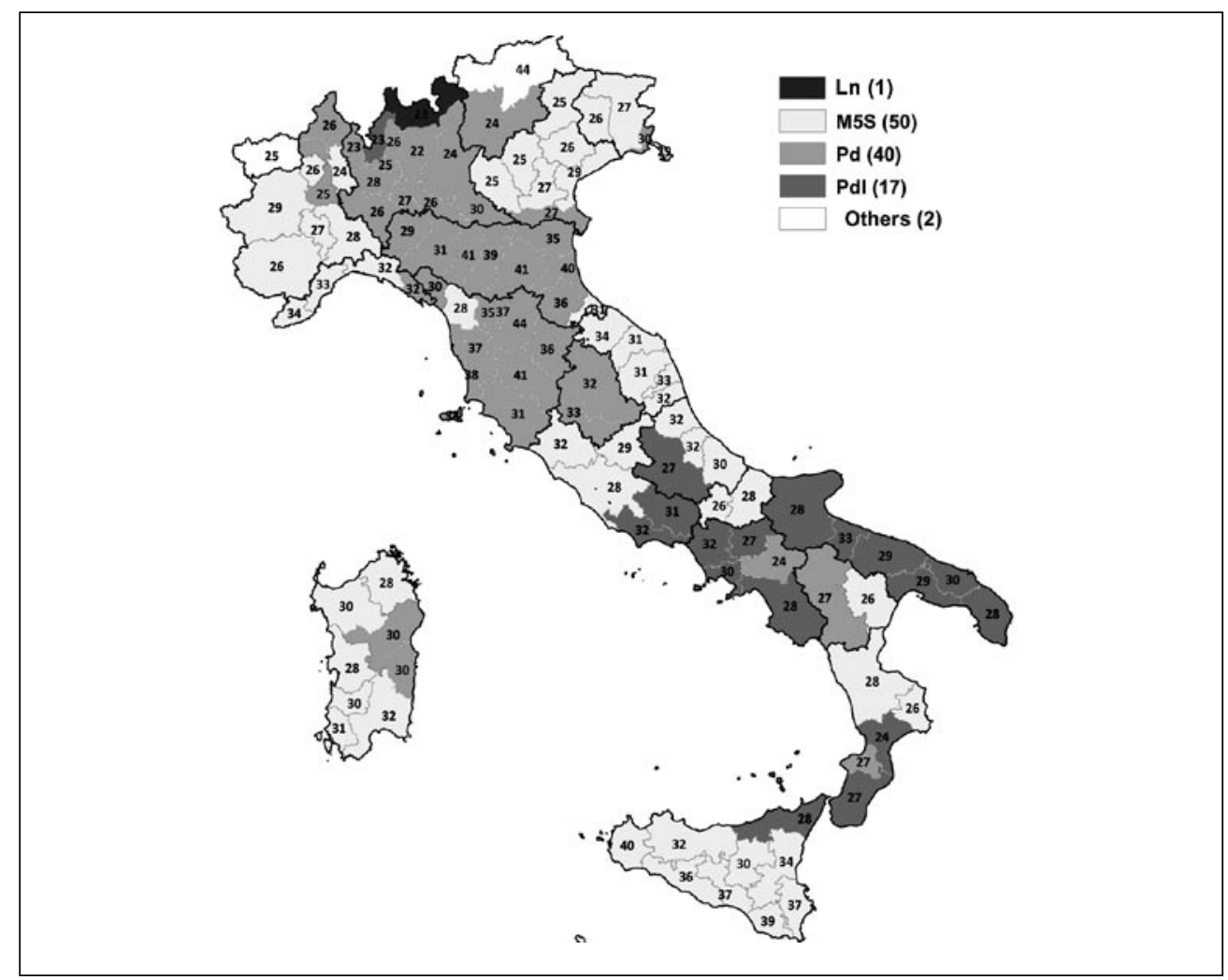

Source: Cataldi and Emanuele (2013).

The M5S has been described as a "web-populist party" (Corbetta and Gualmini 2013; Bordignon and Ceccarini 2013a) but it is also a party that has attracted support from the youngest and most educated sectors of Italian society according to some surveys (Table 2): $35 \%$ of voters aged 18 to 24 voted for it, as well as $29 \%$ of voters holding a university degree and $31 \%$ of those with a high school diploma. The contrast with the PD and the PdL is clear-cut, particularly with the latter. Only $19 \%$ of young people chose the PdL and only $15 \%$ of those with a university degree did the same.

The M5S is also a 'catch-all' party from a social standpoint. In terms of employment/nonemployment status it received more votes than all the other parties from all the sectors excluding retired people and housewives. Even among the self-employed, who have represented for a long time one of the main sources of support for the right-wing parties, today the M5S does better than the PdL. The M5S is also the party that has attracted a higher percentage of manual workers, unemployed and students than the PD. The PdL and the PD do well only among housewives (the PdL) and the retired (the PD). 
Table 1: Vote shifts 2008-2013, Chamber of Deputies: Where M5S voters come from, $\%$, major cities

\begin{tabular}{|c|c|c|c|c|c|c|c|c|c|}
\hline & SA & IdV & PD & UdC & PdL & LN/MpA & Others & Abstentions & $\begin{array}{l}\text { Voter shifts to } \\
\text { Grillo, left/right ratio }\end{array}$ \\
\hline Turin & 36 & 58 & 17 & 0 & 13 & 0 & 23 & 21 & $50 / 19$ \\
\hline Milan & 34 & 33 & 7 & 11 & 2 & 25 & 31 & 16 & $33 / 24$ \\
\hline Pavia & 49 & 0 & 22 & 0 & 0 & 36 & 0 & 7 & $57 / 31$ \\
\hline Varese & 51 & 17 & 12 & 38 & 2 & 21 & 18 & 4 & $37 / 38$ \\
\hline Monza & 45 & 59 & 7 & 0 & 0 & 46 & 41 & 10 & $35 / 44$ \\
\hline Brescia & 20 & 38 & 18 & 0 & 2 & 26 & 8 & 7 & $54 / 34$ \\
\hline Treviso & 0 & 42 & 15 & 33 & 0 & 50 & 0 & 1 & $40 / 50$ \\
\hline Parma & 30 & 11 & 15 & 0 & 0 & 66 & 0 & 45 & $30 / 24$ \\
\hline Pistoia & 7 & 0 & 17 & 46 & 7 & & 39 & 21 & $39 / 12$ \\
\hline Florence & 12 & 13 & 17 & 0 & 0 & 42 & 31 & 18 & $59 / 3$ \\
\hline Ancona & 0 & 55 & 27 & 62 & 0 & 17 & 39 & 28 & $54 / 1$ \\
\hline Rome & 29 & 37 & 10 & 14 & 20 & & 53 & 19 & 26 / 31 \\
\hline Naples* & 39 & 36 & 28 & 16 & 12 & & & 3 & $61 / 26$ \\
\hline Salerno & 21 & 26 & 19 & 0 & 15 & & 5 & 16 & 39 / 34 \\
\hline Reggio Calabria* & 52 & 60 & 15 & 0 & 25 & 71 & 0 & 0 & $34 / 49$ \\
\hline Catania* & & 52 & 23 & 83 & & 64 & & 17 & $24 / 34$ \\
\hline Palermo & 48 & 25 & 27 & 30 & 22 & 26 & 23 & 6 & $35 / 40$ \\
\hline
\end{tabular}

Sources: CISE and *Istituto Cattaneo.

The youngest and the most dynamic sectors of Italian society seem to have chosen in these elections the M5S. Consequently, the first hypothesis to be tested is as follows:

H1. Behind the electoral success of the M5S, there is a generational divide: Young people are more likely to vote for the M5S than adults.

As said previously, this electoral success at the national level was preceded by an electoral growth that had happened through different 'waves' at the local level. In the first wave, the M5S spread in the traditional left-wing regions, i.e. the so-called Red Zone (especially in Emilia-Romagna). Only after the end of the Berlusconi government in 2011, the M5S spread also in the other geopolitical zones of Italy (the last being the South). Therefore, my second hypothesis is as follows:

H2. Political self-placement based on the left-right dimension affects the propensity to vote for the M5S only in the first waves. In other words, I expect that the M5S originally collects consensus especially on the left of the political space, but it loses this ideological characterisation over time.

The next section will present the data of the research, the multi-level analysis design, the dependent variable (the propensity to vote for the M5S) and the independent ones; finally, 
Table 2: Composition of the electorate of the M5S, PD and PdL by age group, level of education and type of work, \% of each category

\begin{tabular}{|c|c|c|c|}
\hline & M5S & PD & PdL \\
\hline Whole sample & 25,6 & 25,4 & 21,6 \\
\hline \multicolumn{4}{|l|}{ By age group } \\
\hline $18-24$ & 35 & 19 & 19 \\
\hline $25-34$ & 29 & 20 & 22 \\
\hline $35-44$ & 34 & 20 & 19 \\
\hline $45-54$ & 32 & 21 & 20 \\
\hline $55-64$ & 20 & 32 & 22 \\
\hline $65+$ & 10 & 37 & 27 \\
\hline \multicolumn{4}{|l|}{ By level of education } \\
\hline University degree & 29 & 27 & 15 \\
\hline High school diploma & 31 & 25 & 18 \\
\hline Middle school & 28 & 23 & 23 \\
\hline Elementary & 14 & 29 & 27 \\
\hline \multicolumn{4}{|l|}{ By type of work } \\
\hline Entrepreneurs, professionals, managers & 25 & 23 & 17 \\
\hline Self-employed & 39 & 15 & 20 \\
\hline Clerks/teachers & 31 & 25 & 15 \\
\hline Manual workers & 29 & 20 & 24 \\
\hline Unemployed & 33 & 18 & 25 \\
\hline Students & 37 & 23 & 11 \\
\hline Housewives & 21 & 22 & 29 \\
\hline Retired & 11 & 37 & 25 \\
\hline
\end{tabular}

Source: IPSOS, Public Affairs. Database: 11026 CATI interviews-pooled pre-election polls, February 18-22, 2013.

section 3 will show the findings of the empirical test verifying if the hypotheses are confirmed or disproved; a concluding section will follow.

\section{Data and Methods}

The basis of this analysis is the comparative method. Precisely, it will be a diachronic comparison and being a large-n study, the analysis will rely on quantitative methods. In fact, I will build a multilevel random-effects regression model $^{3}$ with a pooled data matrix in order to test my hypotheses.

For the abovementioned reasons, I employ individual data (i.e. cross-section and panel surveys data collected from November 2011 to March 2013) from "Osservatorio Politico CISE-Centro Italiano di Studi Elettorali” (http://www.cise.luiss.it). In particular, I employ the voter-level survey data collected from the cross-section survey ${ }^{4}$ held in November 2011 
and the panel study ${ }^{5}$ held from April 2012 to March 2013. The panel study is a longitudinal survey in which variables are measured on the same units over time: In this case, respondents were interviewed before and after the general elections held on 24-25 February 2013. Panel surveys are particularly useful in order to understand changes at the individual level. Furthermore, panel data can also be used to answer typical cross-sectional questions about level and trend.

The analysis is divided into two stages: First, the relevant independent and dependent variables were selected; then, a pooled data matrix and a multilevel random-effects regression model were built. I employed as a dependent variable the propensity to vote for a party (Ptv), following a proven measurement and an analysis strategy developed by some scholars (van der Eijk and Franklin 1996; van der Eijk et al. 2006). In order to organize the independent variables related to individual characteristics, I have decided to follow the "funnel of causality" approach (Campbell et al. 1960). This model describes the voting process in terms of a funnel of causality: In the mouth of the funnel there are the socio-economic conditions that generate society's main political divisions. These factors influence the structure of the party systems, but they are far from the voting decisions of citizens. Moving along the funnel (on the bottom of which is the voting decision), one sees how socio-economic conditions influence the primary groups and values that are more explicitly tied to political attitudes. These attitudes are closely linked to the voting decision and have a strong impact on voting behaviour. All these independent variables are related to different theories of party choice. We have to begin, therefore, with the socio-demographic variables, those that are farthest away from the voting choice. The earliest academic electoral studies stressed the fact that membership in groups defined by social cleavages underlies voting choice (Lazarsfeld et al. 1944; Berelson et al. 1954). The proper theoretical definition of social cleavage theory, however, was made by Lipset and Rokkan (1967): The origins of political parties date back to the lines of social cleavages that underlay political divisions at the time of the introduction of mass suffrage. After selecting the socio-demographic variables ${ }^{6}$, it is necessary to characterise the other independent variables: Mass media used as a source of political information ${ }^{7}$, political awareness ${ }^{8}$, attitudes linked to values ${ }^{9}$, opinions on a specific issue ${ }^{10}$, which are all variables that are closer to voting decisions according to the above cited "funnel of causality" approach. The importance of the media effects during an electoral campaign in the Italian context has been pointed out by several studies (Sani and Legnante 2001; Legnante and Baldassarri 2010). With regard to values, these are relatively stable convictions that carry out the function of providing a guideline of attitudes and actions in several fields. Furthermore, the importance of issues is stressed by theories of issue voting: Voters compare their own position to that of parties defined in terms of specific issues. Voters use such issues as criteria for choice (Converse 1975; Smith 1989; Dalton and Wattenberg 1993; Kuechler 1991). Finally, the last independent variable which has to be included in the model is self-placement along the left/right spectrum ${ }^{11}$. Indeed, rational choice theories propose the idea that voters choose among candidates and parties because of alternative packages of policy outcomes. Alternative sets of policy proposals are often encapsulated in more general ideological dimensions; the most important is the left/right distinction (Downs 1957). The assumption is that voters are able to characterise not only parties in such terms, but also themselves. The party choice can be viewed in terms of a comparison between one's own position and that of parties in terms of ideology. 
As said before, the dependent variable is the propensity to vote (Ptv). The Ptv was measured by asking respondents to report separately for each party the likelihood that they will ever vote for that party.

Moreover, we need a multilevel GLS random-effects model (Verbeke and Molenberghs 2000; Baltagi 2008; Rabe-Hesketh and Skrondal 2008) because of the structure of the data consisting of multiple levels of nested groups. There are, indeed, two levels: Waves and respondents. Waves are nested within respondents. Random intercepts are specified at the respondent level, that is the panel variable ${ }^{12}$. Indeed, GLS random effects models fit the panel data.

This kind of data permits me to investigate whether the profile of supporters of the M5S has changed over time. Moreover, I am able to disentangle the factors which have a greater impact on the propensity to vote for the M5S assuming that this is the main goal of the current analysis. In this regard, I expect to discover changes over time both from a political and social standpoint and with this aim, I run OLS regressions on the Ptv for the M5S, separately for each wave of the study. In other words, I hypothesize that the factors influencing the propensity to vote for the M5S have changed over time in a period characterized by the impressive electoral growth of the M5S.

\section{Findings}

\subsection{The Profile of the Five Star Movement Supporters}

I proceeded to test my hypotheses by creating regression models. However, before the regression analysis, I investigated whether the profile of supporters of the M5S has changed over time, both from a political and a social standpoint. In order to do so, I used the individual data from "Osservatorio Politico-CISE" by cross-tabulating the propensity to vote for the M5S and some political and socio-demographic variables. As said before, the propensity to vote for the M5S has been measured on an eleven-point scale from "certainly would never vote for this party" to "certainly would vote for this party at some time". In this way, I can identify the core supporters of the M5S. Indeed, the Ptv is useful for two reasons: Firstly, it allows us to detect the orientations of the whole sample, since almost all of the respondents answered these questions (whereas with regard to the voting intentions only a minority responds, and for smaller parties, such as the M5S in the first waves, the number of cases is therefore very low); secondly, the Ptv allows us to identify the electoral potential of a party by selecting those who show a high probability to vote for that party. Therefore, I recoded the Ptv for the M5S into three categories: "Very unlikely" (values from 0 to 4), "maybe" (value of 5), "very likely" (values from 6 to 10). A Ptv value of more than five thus indicates the electoral potential of a certain party and in the cross-tabulations I consider the Ptv for the M5S only if it is more than five. In this way, I can outline the profile of the M5S supporters over time.

As can be seen in Figure 2, the electoral potential of the M5S increases linearly during our period of investigation: In the first wave (November 2011) M5S supporters (Ptv>5) represent $15.6 \%$ of respondents and in the post-electoral panel wave (March 2013) they represent 33\%. The trend analysis suggests the increasing electoral potential of the M5S. But how great is the probability of becoming a supporter of the M5S? In order to answer this question, 
I transformed data from long into wide format and I calculated the percentage of individuals moving from very unlikely voters (Ptv between 0 and 4 ) to very likely voters $(\operatorname{Ptv}>5)$. A simple cross-tabulation between the Ptv for the M5S in April 2012 and the Ptv for the M5S in March 2013 shows the percentage of people that moved into or out the electoral potential of the M5S. The Ptv for the M5S is distinguished into the three aforementioned categories. Table 3 summarizes the results of the panel analysis and shows the Ptv for the M5S of April 2012 in the rows and the Ptv for the M5S of March 2013 in the columns. Of those individuals that were very unlikely voters of the M5S in April 2012, 63.8\% are also unlikely voters of the M5S in March 2013, while 12.8\% entered the "maybe" category and 23.4\% became very likely voters of the M5S in March 2013. Therefore, the probability of becoming a supporter of the M5S is $23.4 \%$. Of those individuals that were very likely voters of the M5S in the first panel wave, $63 \%$ are also very likely voters in the last panel wave, while $25.6 \%$ became very unlikely voters of the M5S and $11.4 \%$ entered the "maybe" category in the last panel wave. The percentage of those who moved into the electoral potential of the M5S is almost the same as those who became very unlikely voters of the M5S. Those who stayed in their original status are around $63 \%$. Therefore, those who changed their status are the minority. The category less stable over time is the "maybe" category. In this case, those who changed their status are the majority: $43.9 \%$ became very unlikely voters and $31.7 \%$ became very likely voters of the M5S. In synthesis, it can be said that at the individual level there is more stability than suggested by the trend analysis.

Figure 2: Propensity to vote for the M5S over time ( $N=1395 ; 2945 ; 2515 ; 2032 ; 1494)$

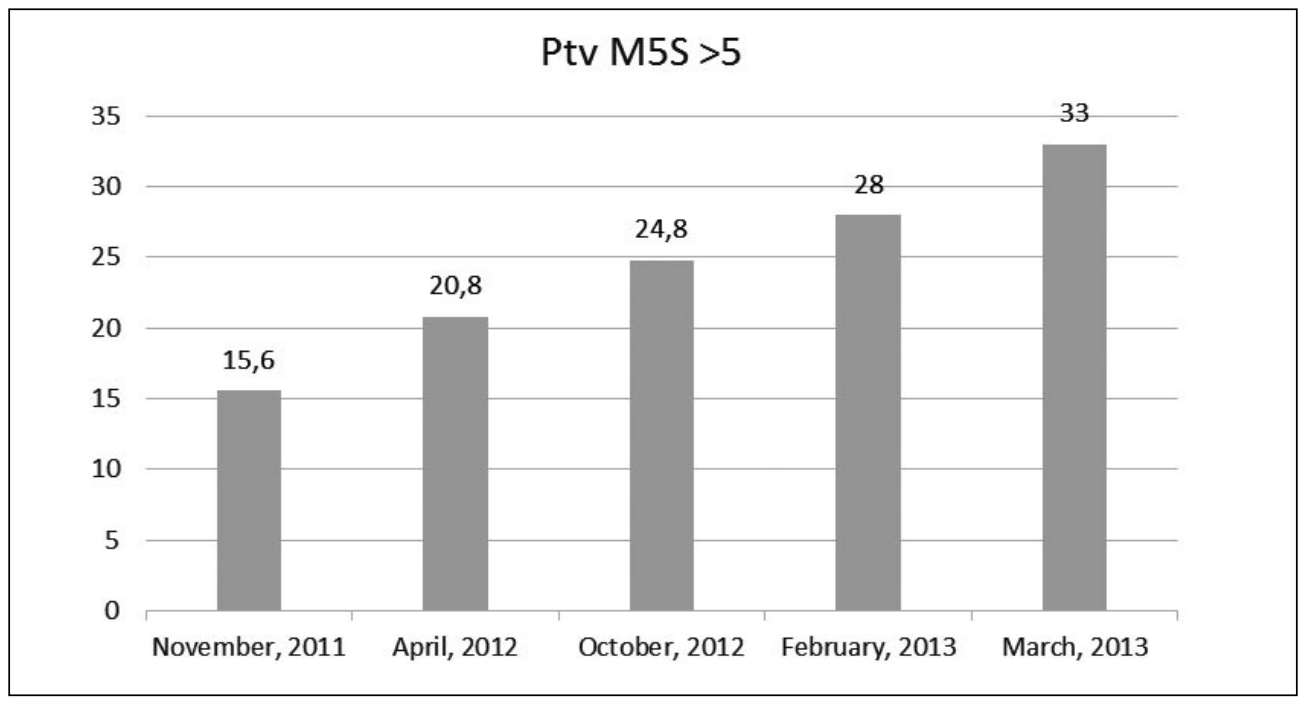

Source: Author. 
Table 3: M5S Ptv dynamics (April 2012-March 2013), \% of each category.

\begin{tabular}{|l|c|c|c|c|c|}
\hline & \multicolumn{5}{|c|}{ Ptv for the M5S, March 2013 } \\
\hline $\begin{array}{l}\text { Ptv for the M5S, } \\
\text { April 2012 }\end{array}$ & $\begin{array}{c}\text { Very unlikely } \\
\text { voters }\end{array}$ & Maybe & $\begin{array}{c}\text { Very likely } \\
\text { voters }\end{array}$ & Total & N (total 930) \\
\hline Very unlikely voters & 63.8 & 12.8 & 23.4 & 100 & 611 \\
\hline Maybe & 43.9 & 24.4 & 31.7 & 100 & 110 \\
\hline Very likely voters & 25.6 & 11.4 & 63.0 & 100 & 209 \\
\hline
\end{tabular}

Source: Author.

With regard to the political self-placement along the left-right scale, the M5S shows a crosscutting profile and this fact is accentuated over time (Figure 3). Indeed, while in the first wave the percentage of the leftist supporters of the M5S was much higher than the percentage of the right-wing supporters ( $44.5 \%$ vs. $26 \%$ ), this gap decreases over time and in the last wave left and right show more or less the same percentage among the M5S supporters. The percentage of those who do not place themselves along the left-right scale also increases significantly from the first wave to the pre-electoral wave (February 2013). Therefore, the M5S shows an ability in collecting preferences which crosscuts the entire political spectrum.

Figure 3: Political profile of potential M5S voters (Ptv $>5)$ by self-placement along the left-right scale over time $(\mathrm{N}=1397 ; 2949 ; 2513 ; 2031 ; 1492)$

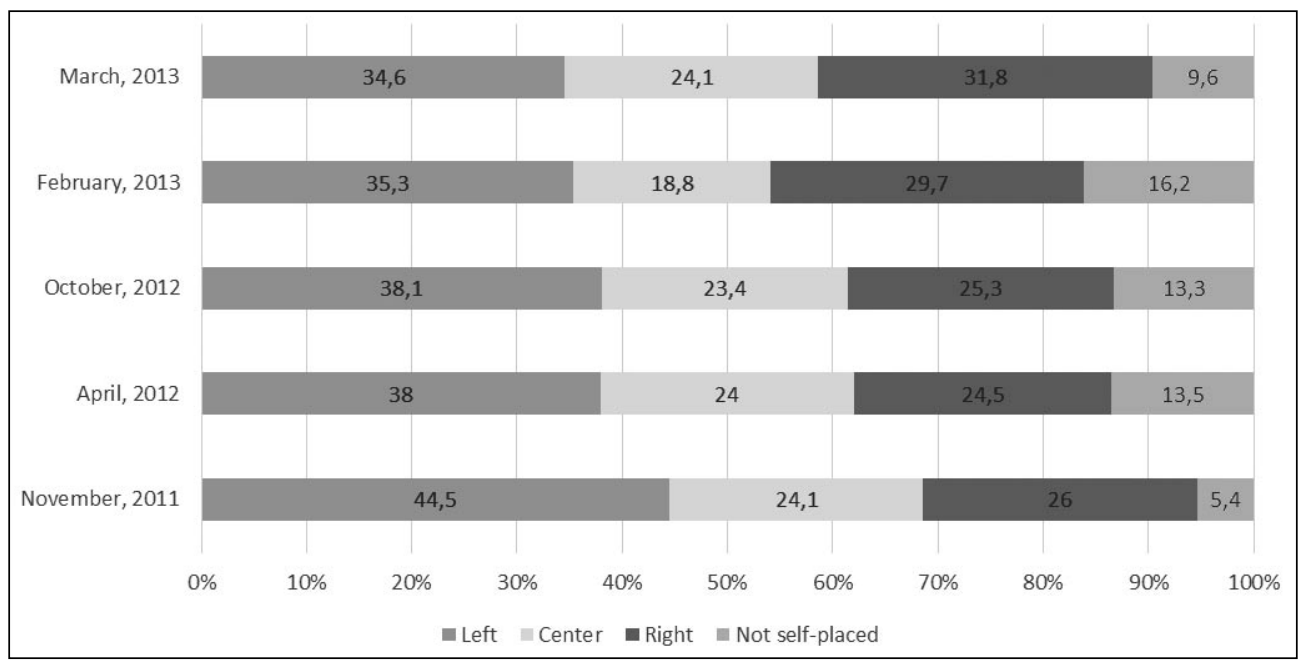

Source: Author.

The M5S supporters show a cross-cutting profile also from a socio-demographic standpoint. In terms of gender, the potential voters of the M5S display more or less the same percentage of females and males over time, with a prevalence of male supporters (Figure 4). Even if we look at the profile of potential M5S voters by age group, we can notice that 
Figure 4: Socio-demographic profile of potential M5S voters $(\mathrm{Ptv}>5)$ by gender over time ( $\mathrm{N}=1397 ; 2949 ; 2513 ; 2031 ; 1492)$

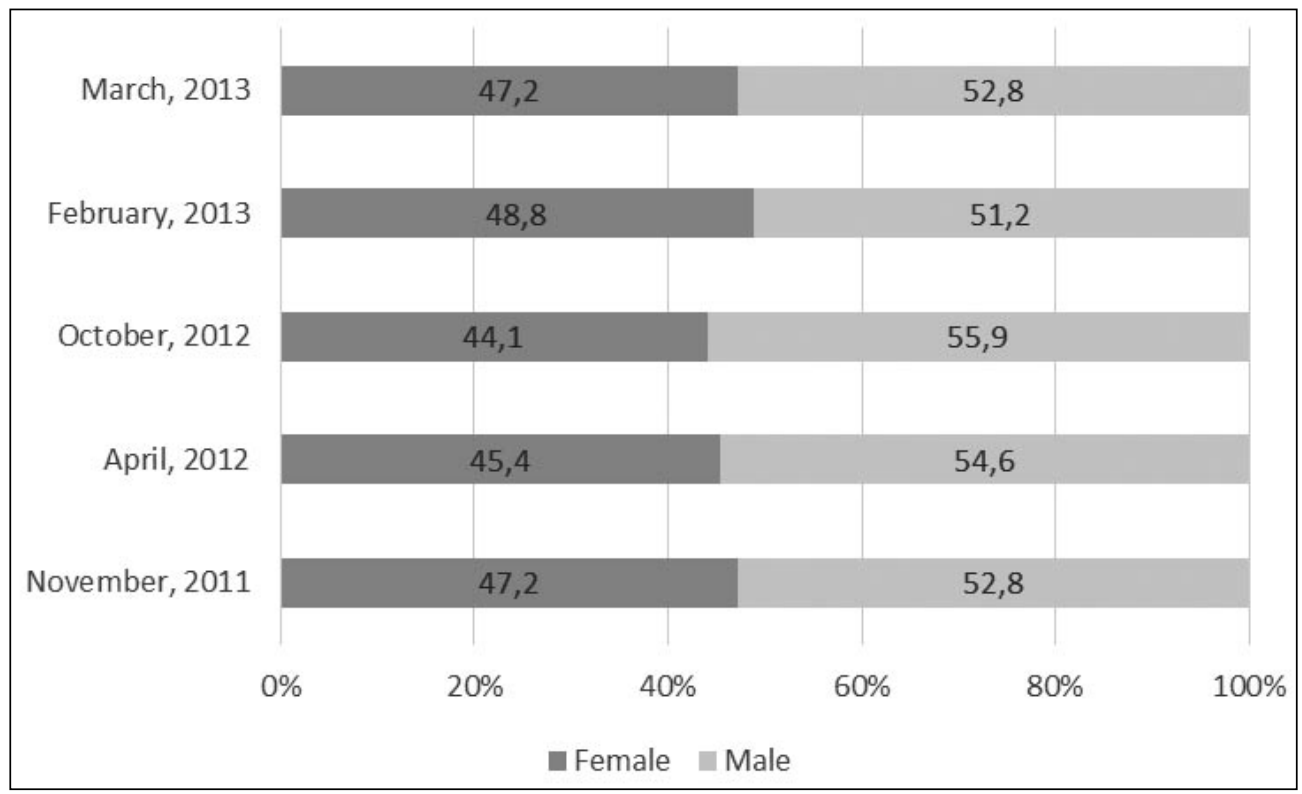

Source: Author.

Figure 5: Socio-demographic profile of potential M5S voters (Ptv $>5)$ by age group over time (N=1397; 2938; 2505; 2027; 1489)

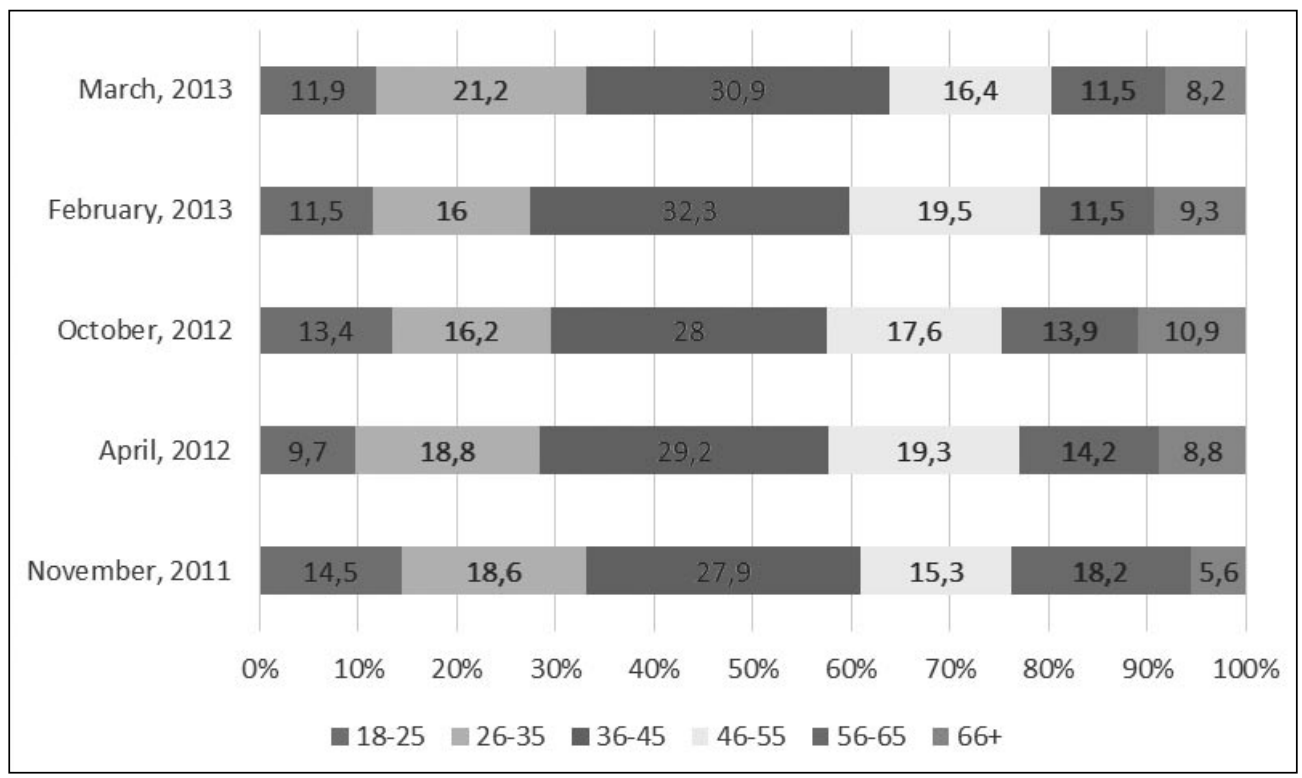

Source: Author. 
different generations are well represented among the M5S supporters and not only the youngest ones (Figure 5). Indeed, in the first wave those who are 18-35 years old represent $33.1 \%$ of the electoral potential of the M5S and those who are 36-55 years old represent $43.2 \%$ of the M5S supporters. In the last wave, those who are 18-35 years old still represent $33.1 \%$ of the electoral potential of the M5S and those who are 36-55 years old represent $47.3 \%$ of the M5S supporters. Nonetheless, the young and the middle age groups are over-represented among the M5S supporters with respect to the whole sample, whereas the two older age groups are under-represented among the potential M5S voters if compared to the average.

The M5S supporters show a clear cross-cutting profile also in terms of employment/nonemployment status: Figure 6 is represented by a perfect rainbow over time. In particular, we can notice that in the pre-electoral wave retired people are the smallest category, while manual workers are the largest category. If we consider the level of education, the profile of the M5S supporters is more clear-cut: In each wave, those holding a secondary school and a high school diploma represent the largest category among the M5S supporters. Conversely, those with an elementary education are almost always the smallest category in the M5S electorate (Figure 7).

These results related to the socio-demographic profile of M5S voters are generally consistent with those of other empirical studies (Bordignon and Ceccarini 2013b).

Finally, it can be noticed that over time the relative share of M5S supporters from the Centre-South increases, whereas those from the Red Zone and, to some extent, those from the North decrease (Figure 8).

Figure 6: Socio-demographic profile of potential M5S voters (Ptv $>5)$ by profession over time ( $N=1393 ; 2941 ; 2511 ; 2031 ; 1492)$

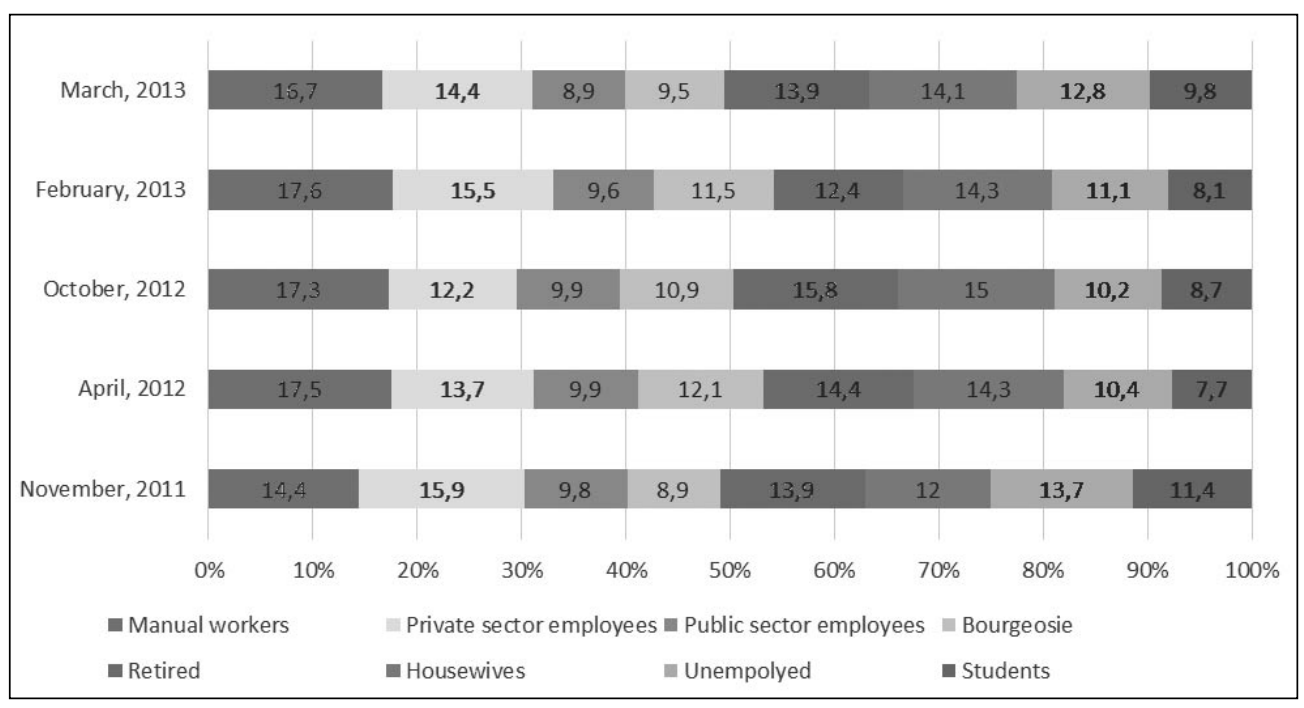

Source: Author. 
Figure 7: Socio-demographic profile of potential M5S voters (Ptv $>5)$ by level of education over time $(\mathrm{N}=1397 ; 2945 ; 2510 ; 2029 ; 1490)$

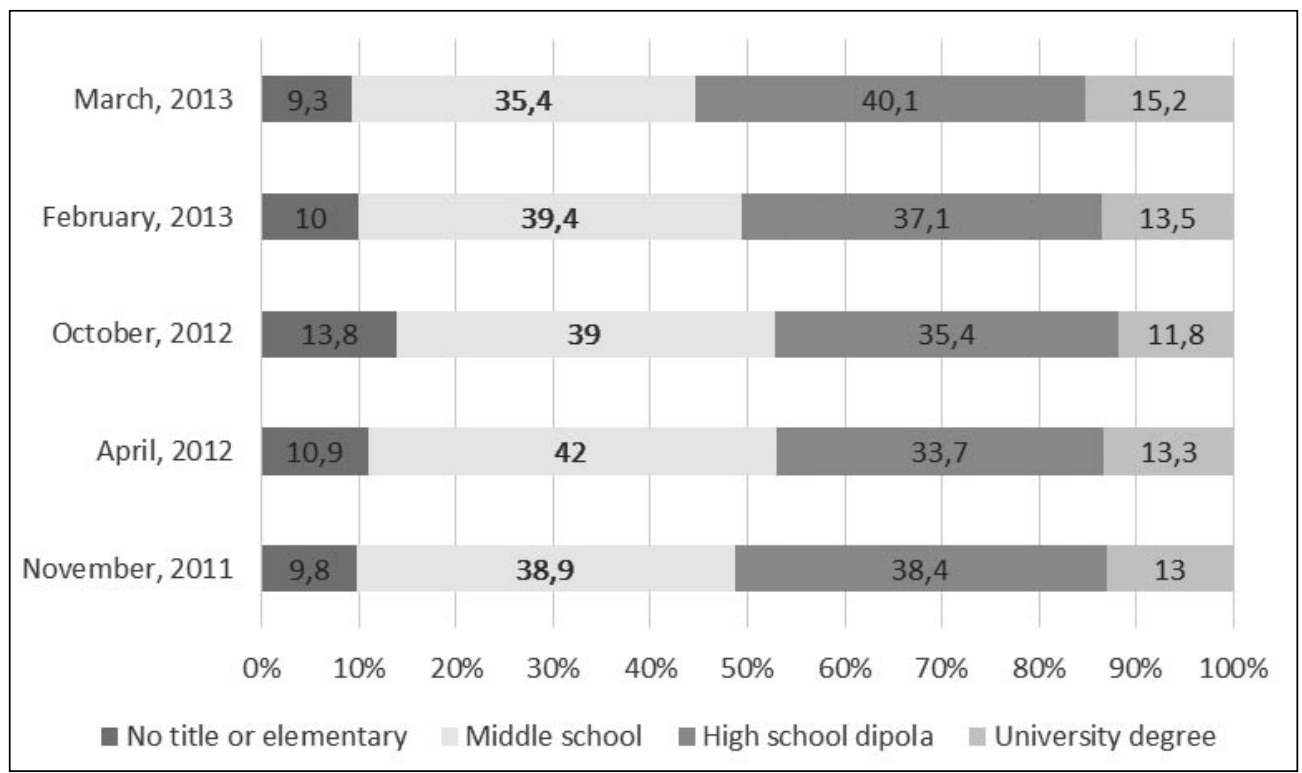

Source: Author.

Figure 8: Socio-demographic profile of potential M5S voters $(\mathrm{Ptv}>5)$ by geographical area of residence over time $(\mathrm{N}=1397 ; 2936 ; 2503 ; 2028 ; 1489)$

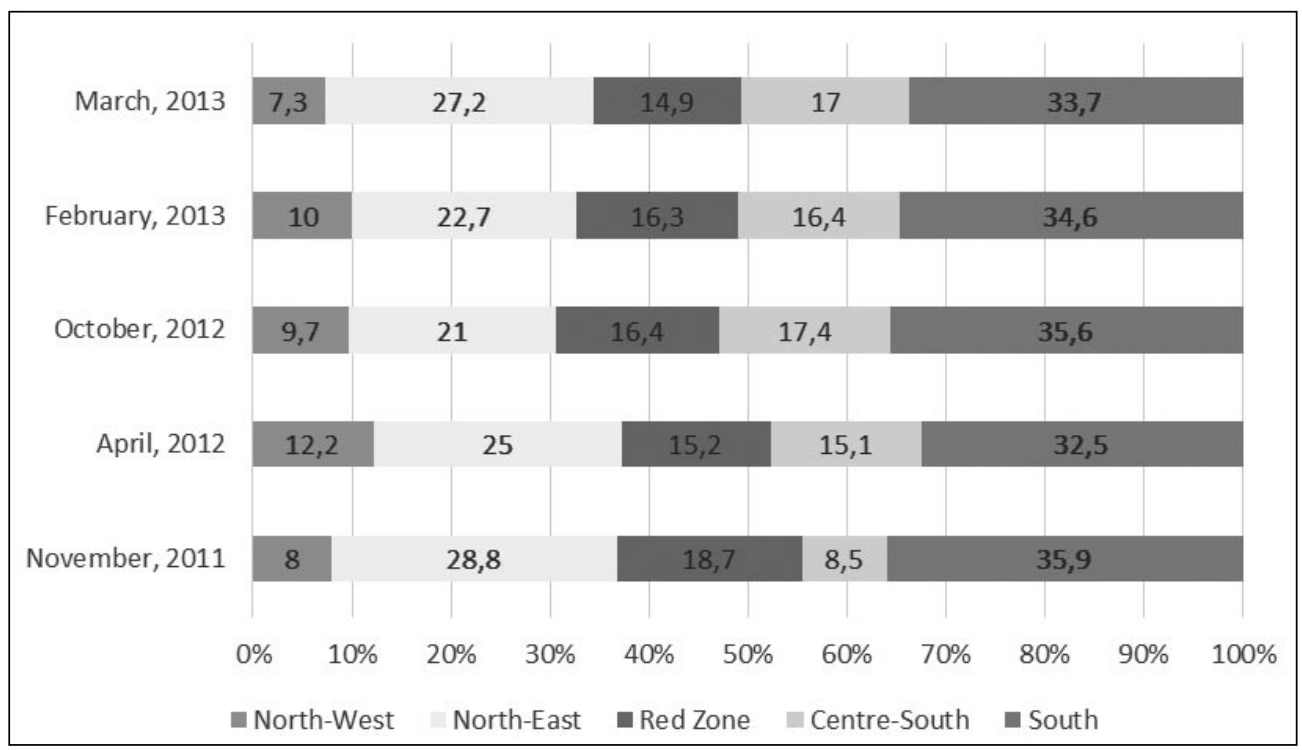

Source: Author. 


\subsection{The Determinants of the Vote for the Five Star Movement}

I have just described the profile of the M5S supporters and its changes over time in a period characterized by the electoral growth of the Grillo movement ending up with great success at the 2013 general election. However, the main goal of the current analysis is to find out the factors which have a greater impact on the propensity to vote for the M5S. For this purpose, as said in the previous paragraph, I have created a multilevel GLS random-effects model. Furthermore, I have redefined the dependent variable: It is no longer the Ptv for the M5S, but the 'relative' Ptv for the M5S. That is to say, I have calculated the mean Ptv for all the parties and I have subtracted it from the Ptv for the M5S. In this way, I obtain a measure that permits us to consider the true propensity to vote for the M5S. Indeed, there are respondents who give a high Ptv score not only to the M5S, but also to other parties: These are not real M5S supporters and I need to take into account this fact by creating the relative Ptv for the M5S. Then I have included in the pooled model the set of independent variables presented in the previous paragraph: Socio-demographic variables ${ }^{13}$; political interest; Internet as the main source of political information; attitudinal variables (libertarian values index and opinions on Euro membership); political self-placement ${ }^{14}$. Furthermore, I have included in the model dummies identifying the waves of the panel study ${ }^{15}$ in order to take into account the variance due to different period effects. The results of estimation are presented in Table 4, which includes $b$ coefficients (with standard errors) as well as goodness-of-fit statistics. The table reports how differences in the propensity to vote for the M5S (the dependent variable) are shaped by differences in the independent variables. As we can see, the time/wave dummies are all statistically significant and their coefficients increase linearly over time with respect to the reference category (i.e. the first wave of the panel). Looking at the $b$ coefficients and to the standard errors of the predictors, we can notice that gender, some professional categories, church attendance, a specific geographical zone (i.e. the South), Internet as the main source of political information, the libertarian values index, the anti-Euro issue, a specific category of the left-right dimension (i.e. those not self-placed along such dimension), are all variables having an influence on the Ptv for the M5S. It is important to notice that variables such as education, age ('young dummy') and political interest are not significant. The level of education and the level of political involvement, such as the young age, do not seem to be linked to the probability to vote for the M5S. This result is contrary to expectations because in the first paragraph we have seen that the youngest and most educated people voted more for the M5S than for the main parties. Nonetheless, young age and level of education are not explanatory factors of the vote for the M5S when other individual characteristics are taken into account. Therefore, H1 has not been confirmed: Young age (18-25) is not a predictor of the Ptv for the M5S.

At the same time, ideological categories in terms of left and right do not matter. Indeed, Centre and Right dummies with respect to the Left dummy do not have any impact on the M5S support. This means that there are no significant differences in terms of left and right among M5S voters. Conversely, the dummy identifying those who do not place themselves on the left-right dimension is very significant at a level of $1 \%$. In other words, the probability of voting for the M5S increases among those who reject the traditional left-right axis in comparison with those who place themselves on the left. 
If we look at the geographical area of residence, only the dummy identifying the South with respect to the North-West is significant (at a 5\% level of statistical significance). This means that the geographical area of residence of the respondent does not show a great discriminative ability among M5S voters, except the fact of living in the South. In this case, the probability of voting for the M5S increases among those living in the South in comparison with those living in the North-West.

A greater impact on the propensity to vote has been shown by some professional categories. The categories of the retired and housewives (in comparison with the category of manual workers) are negatively correlated with the Ptv for the M5S and they are good predictors of the Ptv for the M5S both in terms of strength of the coefficient and of the level of statistical significance. These dummies, indeed, are significant at a $0.1 \%$ level (retired people) and at a $1 \%$ level (housewives) and their coefficients are high. In particular, the coefficient for housewives is -0.9 and the coefficient for the retired is -1.5 .

Table 4: Estimated effects on the propensity to vote for the M5S for some predictors, pooled dataset

\begin{tabular}{|c|c|c|}
\hline Gender (male) & $0.421^{\star *}$ & $(0.145)$ \\
\hline Young & -0.169 & $(0.358)$ \\
\hline \multicolumn{3}{|l|}{ Elementary (reference category) } \\
\hline Secondary school & 0.093 & $(0.307)$ \\
\hline High school diploma & -0.140 & $(0.287)$ \\
\hline University degree & -0.561 & $(0.304)$ \\
\hline \multicolumn{3}{|l|}{ Manual workers (reference category) } \\
\hline Private sector employees & -0.323 & $(0.261)$ \\
\hline Public sector employees & -0.185 & $(0.275)$ \\
\hline Bourgeoisie & -0.496 & $(0.272)$ \\
\hline Retired & $-1.518^{\star \star \star}$ & $(0.247)$ \\
\hline Housewives & $-0.940^{* *}$ & $(0.303)$ \\
\hline Unemployed & -0.212 & $(0.347)$ \\
\hline Students & -0.686 & $(0.365)$ \\
\hline Church attendance & $-0.685^{\star \star \star}$ & $(0.202)$ \\
\hline \multicolumn{3}{|l|}{ North-West (reference category) } \\
\hline North-East & -0.085 & $(0.228)$ \\
\hline Red Zone & -0.063 & $(0.256)$ \\
\hline Centre-South & 0.044 & $(0.258)$ \\
\hline South & $0.542^{*}$ & $(0.242)$ \\
\hline Political interest & 0.126 & $(0.200)$ \\
\hline Internet as source of information & $0.681^{* * *}$ & $(0.133)$ \\
\hline Libertarian values index & $0.951^{* *}$ & $(0.304)$ \\
\hline Issue No Euro & $1.657^{\star \star *}$ & $(0.244)$ \\
\hline \multicolumn{3}{|l|}{ Left (reference category) } \\
\hline Centre & 0.160 & $(0.119)$ \\
\hline Right & 0.105 & $(0.133)$ \\
\hline Not Self-Placed & $0.613^{\star *}$ & $(0.194)$ \\
\hline
\end{tabular}




\begin{tabular}{|l|c|c|}
\hline Wave 201204 (reference category) & $0.379^{\star \star \star}$ & $(0.085)$ \\
\hline Wave 201210 & $0.525^{\star \star \star}$ & $(0.094)$ \\
\hline Wave 201302 & $0.824^{\star \star \star}$ & $(0.108)$ \\
\hline Wave 201303 & -0.285 & $(0.463)$ \\
\hline constant & 1.96 & \\
\hline Sigma_u & 2.04 & \\
\hline Sigm_e & 0.48 & \\
\hline Rho (fraction of variance due to u_i) & 0.02 & \\
\hline R-squared: Within & 0.25 & \\
\hline R-squared: Between & 0.17 & \\
\hline R-squared: Overall & 4172 & \\
\hline N & \multicolumn{2}{|l}{} \\
\hline Note: Standard errors in parentheses; significant at ${ }^{*} p<0.05,{ }^{* \star} p<0.01,{ }^{* \star *} p<0.001$ levels. \\
\hline
\end{tabular}

Source: Author.

This means that the probability of voting for the M5S hugely decreases among retired people and housewives in comparison with manual workers. Conversely, belonging to the working class increases the probability of voting for the M5S. With regard to the occupational categories not mentioned, there are not significant differences between such categories and manual workers in terms of the propensity to vote for the M5S. This means that the electoral support for the M5S crosscuts all the sectors of the labour market.

A negative impact on the propensity to vote for the M5S has been exercised by another sociological variable: Church attendance. Indeed, such a variable shows a negative sign for the coefficient and it is very significant at the level of $0.1 \%$. This means that an increase in church attendance is associated with a decrease in the Ptv for the M5S: Supporters of the Grillo movement are likely among those who are not religious practitioners. This result is consistent with that for the index of libertarian values. Indeed, such an index is significant at the level of $1 \%$ and its coefficient is high, meaning that libertarian values have an influence on the propensity to vote for the M5S. Since the sign of the coefficient is positive, we can say that people with libertarian opinions on moral topics are more likely to vote for the M5S. It is important to notice that the traditional dimension based on left and right does not have any influence on the Ptv for the M5S, whereas the cultural dimension linked to values does matter. This seems to confirm what was suggested by Flanagan (1982), namely that a new cultural axis of political polarization based on the Authoritarian-Libertarian distinction would have added to the political space alongside the traditional economic axis based on the left-right distinction.

Finally, two variables are particularly linked to the Ptv for the M5S: The anti-Euro issue and the dummy identifying Internet as the main source of political information. Both variables are very significant at $0.1 \%$ and their coefficients are 1.7 and 0.7 respectively. This means that anti-Euro attitudes and the use of the web as the main source of political information are associated with the Ptv for the M5S. The first result leads to point out that for M5S voters the European Union is a matter of political distinction, maybe another axis of political polarization alongside the cultural axis and the left-right axis (and the last one is not useful in order to explain the vote for the M5S). 
The second result is very interesting because it shows that the kind of media used in order to achieve information about politics is an important factor when we want to explain the vote for the M5S. The success of the M5S has been often interpreted as the consequence of a generational cleavage: A sort of rebellion of young people, with a triumph of the M5S in the youngest age group. In reality, in our regression model the dummy identifying the youngest voters is not significant from a statistical point of view. Indeed, as we have seen previously, the Grillo movement obtains percentages above the average in the age groups up to 54. Young people are not the only ones particularly attracted to the M5S. Behind the electoral success of the M5S, there is actually a technological divide. Indeed, our data shows that there is a strong relationship between the prevailing means of political information and the Ptv for the M5S. People who obtain political information mainly through the web are more likely to vote for the M5S, a movement that is present in a more systematic, widespread and professional way on the web when compared to the traditional parties.

Until now we have seen which factors are linked to the propensity to vote for the M5S. In order to discover if these factors have changed over time I have run OLS regressions on the Ptv for the M5S, separately for each wave of the study (Table 5). In order to enlarge the time span, I have considered also the data from the wave of November 2011. With this aim, I have included in the regression models only the variables that are present in all the five waves.

As can be seen in Table 5, there are changes over time with regard to the factors influencing the Ptv for the M5S. For what concerns the socio-demographic variables, gender has an influence on the Ptv for the M5S only in Model B and in Model C (April and October 2012). In the pre-electoral and post-electoral waves (Model D and Model E) this variable is no longer significant (as in Model A). In general, it can be said that gender is not one of the most powerful predictors of the Ptv for the M5S. With regard to the age effects, we have recoded age in different age groups (each one represented by a dummy variable and the 18-25 age group is the reference category). In Model B, the $26-35$ age group is statistically significant (at a 5\% level) and positively correlated with the Ptv for the M5S with respect to the youngest age group (18-25). Conversely, in Models C and D those who are more than 55 years old are less likely to vote for the M5S with respect to those who are 18-25 years old. In model E (the postelectoral wave), this is true for those over 45. It has been confirmed that the M5S receives less support among the old voters, but there is no difference from a statistical standpoint between young and middle-aged voters.

If we look at the level of education, it has been confirmed that this variable is not useful to explain the propensity to vote for the M5S. Just two categories are significant in two waves: The dummy identifying those with a high school diploma compared to those with elementary education in Model A (at a 1\% level of significance) and the dummy identifying those with a university degree compared to those with elementary education in Model C (at a 5\% level). In November 2011, those with a high school diploma were more likely to vote for the M5S than those with elementary education, whereas in October 2012 those with a university degree were less likely to vote for the M5S than those with elementary education.

With regard to the employment/non-employment status, it can be noticed that there are some interesting changes over time. In the first three waves, this variable does not have any influence on the Ptv for the M5S. In the pre-electoral wave (Model D), dummies for retired 
people and housewives become significant at a 5\% level and negatively correlated with the Ptv for the M5S. This point confirms the fact that the probability of voting for the M5S decreases among the retired and housewives in comparison with manual workers. In the post-electoral wave (Model E), the categories of retired people and housewives are no longer significant, while the student dummy becomes significant at a 5\% level and negatively associated with the Ptv for the M5S in comparison with manual workers. This data tells us that in the post-electoral wave students are less likely to vote for the M5S in comparison with manual workers. This is interesting because we have seen that young people are more likely to vote for the M5S than older ones, and students are young. But if we take into account the professional categories, students are not positively correlated with the Ptv for the M5S in comparison with manual workers. It is not the young age, but the working class status that seems to be associated with M5S support.

With regard to another sociological variable (church attendance), there is continuity over time: It always shows a negative sign for the beta coefficient and it is almost always very significant (except in Models A and D). This means that such a variable is a powerful predictor of the Ptv for the M5S: An increase in church attendance is associated over time with a decrease in the probability to vote for the M5S.

Conversely, the variable measuring the level of political interest of the respondent is never significant, except in October 2012 (when it reaches the level of significance of $0.1 \%$ and it is positively associated with the Ptv for the M5S). In general, it has been confirmed that the level of political involvement is not an explanatory factor of the vote for the M5S.

As far as the geographical area of residence is considered, there are changes over time. In the first wave, such a variable is not significant. On the contrary, in the second wave (Model B) all the geographical categories (except the South) become significant with respect to the reference category (i.e. North-West) and are all negatively correlated with the Ptv for the M5S. This means that living in the North-West increases the probability of voting for the M5S. This is true in particular in contrast with those who live in the North-East and in the Red Zone: These dummies are significant at a $1 \%$ level and their (negative) beta coefficients are higher than the coefficient of the other geographical category (i.e. Centre-South). Indeed, in Model C (October 2012) only the dummies for the North-East and Red Zone keep their statistical significance. This means that there is no longer a difference between those living in the North-West and those living in the Centre-South in terms of the propensity to vote for the M5S. Finally, in Model D (February 2013, few days before the elections) there is no longer any statistical difference between the different geographical areas of the country in terms of the propensity to vote for the M5S. In Model E (March 2013) only the dummy identifying the South with respect to the North-West is significant (at 1\% level) and the sign of the association has changed becoming positively correlated with the Ptv for the M5S. As said with regard to pooled analysis, this means that the geographical area of residence of the respondent does not show a great discriminative ability among M5S voters, except the fact of living in the South. In this case, the Ptv for the M5S increases among those living in the South in comparison with those living in the North-West. Therefore, from April 2012 to March 2013 the relationship between geography and voting for the M5S has been reversed: Living in the North-West no longer increases the probability of voting for the M5S compared to living in the South, but the reverse is true. 
Finally, the influence of ideological categories on the Ptv for the M5S also changes over time. Indeed, the Right dummy with respect to the Left dummy is significant in Model A (November 2011), in Model B (April 2012) and in Model C (October 2012). In particular, the Right dummy is very significant (at a $0.1 \%$ level in Models A and B; at a $1 \%$ level in Model C) and its beta coefficient is the highest in the first two waves. This ideological category is negatively correlated with the Ptv for the M5S: placing on the right-wing of the political space decreases the probability of voting for the M5S. Conversely, leftist respondents are more likely to vote for the M5S in the first three waves. Things change in the last two waves: The dummy identifying those who do not place themselves on the left-right scale becomes very significant (at a $0.1 \%$ level), while the right-wing category is no longer significant. On the contrary, in the first three waves the dummy identifying those who do not place themselves on the left-right dimension was never significant. Consequently, there are no longer significant differences in terms of left and right among the M5S voters as previously shown by the pooled analysis. Therefore, from November 2011 to March 2013 there was a sharp change from the ideological point of view among the supporters of the M5S: Being leftist no longer increases the probability of voting for the M5S in comparison with those who are right-wing supporters, whereas rejecting the left-right dimension increases the Ptv for the M5S. In other words, according to H2, the M5S originally collects consensus especially on the left, but this ideological characterization is lost over time. All this happens in a period of electoral growth for the M5S and it confirms the cross-cutting profile of the Grillo movement.

As stated previously, the results shown in Table 5 are not able to consider some important variables included in the pooled analysis. These variables are the libertarian values index, the anti-Euro issue and the dummy identifying Internet as the main source of political information for the respondent. According to the pooled analysis, all these variables affect the Ptv for the M5S. Therefore, I included such variables in the OLS regression models only for the panel waves. Table 6 shows the goodness-of-fit of OLS regressions for each panel wave comparing the model without these three predictors (base model) and the model that includes these predictors (full model). It can be noticed that in each panel wave the variance explained by the full model is much more than the variance explained by the base model: $17 \%$ vs. $10 \%$ in April 2012; $16 \%$ vs. $10 \%$ in October 2012; $21 \%$ vs. $12 \%$ in February 2013; $29 \%$ vs. $21 \%$ in March 2013 . Because of the three variables included in the regression models, the R-squared increases by 0.077 in April 2012, by 0.068 in October 2012, by 0.091 in February 2013 and by 0.087 in March 2013. Therefore, the overall predictive power of the full model is always greater than the overall predictive power of the base model. Furthermore, the AIC and BIC coefficients for the full model decrease considerably in each wave with respect to the base model: The lower the AIC and BIC coefficients, the better the model fits the data. All this means that the goodness-of-fit of the regression models increases significantly when a media-related variable and variables linked to values and to attitudes towards the European Union are taken into account. Using Internet as the main source of political information, being open-mind with regard to moral topics and having negative attitudes towards the Euro increase the probability of voting for the M5S. 
Table 5: Estimated effects on the propensity to vote for the M5S for some predictors over time

\begin{tabular}{|c|c|c|c|c|c|c|c|c|c|c|}
\hline & \multicolumn{2}{|c|}{$\begin{array}{c}\text { Model A } \\
(2011-11)\end{array}$} & \multicolumn{2}{|c|}{$\begin{array}{l}\text { Model B } \\
(2012-04)\end{array}$} & \multicolumn{2}{|c|}{$\begin{array}{l}\text { Model C } \\
(2012-10)\end{array}$} & \multicolumn{2}{|c|}{$\begin{array}{c}\text { Model D } \\
(2013-02)\end{array}$} & \multicolumn{2}{|c|}{$\begin{array}{l}\text { Model E } \\
(2013-03)\end{array}$} \\
\hline & beta & s.e. & beta & s.e. & beta & s.e. & beta & s.e. & beta & s.e. \\
\hline Gender (male) & 0.036 & $(0.157)$ & $0.065^{\star \star}$ & $(0.138)$ & $0.076^{\star \star}$ & $(0.171)$ & 0.045 & $(0.204)$ & 0.042 & $(0.238)$ \\
\hline Age 26-35 & 0.074 & $(0.434)$ & $0.072^{*}$ & $(0.288)$ & 0.011 & $(0.393)$ & -0.052 & $(0.586)$ & 0.002 & $(0.592)$ \\
\hline Age $36-45$ & 0.037 & $(0.445)$ & 0.077 & $(0.280)$ & -0.009 & $(0.396)$ & -0.012 & (0.609) & -0.068 & (0.624) \\
\hline Age 46-55 & 0.018 & $(0.458)$ & -0.010 & $(0.295)$ & -0.083 & $(0.408)$ & -0.059 & $(0.608)$ & $-0.155^{*}$ & $(0.637)$ \\
\hline Age 56-65 & -0.041 & $(0.485)$ & -0.041 & $(0.333)$ & $-0.140^{\star \star}$ & $(0.423)$ & $-0.159^{*}$ & (0.643) & $-0.311^{\star \star \star}$ & (0.651) \\
\hline Age 66+ & -0.115 & $(0.489)$ & -0.083 & $(0.364)$ & $-0.169^{\star \star}$ & $(0.484)$ & $-0.178^{\star}$ & $(0.674)$ & $-0.389^{\star \star \star}$ & (0.689) \\
\hline $\begin{array}{l}\text { Secondary } \\
\text { school }\end{array}$ & 0.071 & $(0.230)$ & 0.025 & $(0.245)$ & -0.049 & $(0.301)$ & -0.004 & $(0.353)$ & 0.055 & $(0.444)$ \\
\hline $\begin{array}{l}\text { High school } \\
\text { diploma }\end{array}$ & $0.128^{\star \star}$ & $(0.256)$ & 0.028 & $(0.250)$ & -0.053 & $(0.296)$ & -0.031 & $(0.352)$ & 0.045 & $(0.437)$ \\
\hline $\begin{array}{l}\text { University } \\
\text { degree }\end{array}$ & 0.047 & $(0.265)$ & -0.007 & $(0.278)$ & $-0.071^{*}$ & $(0.317)$ & -0.048 & $(0.384)$ & -0.019 & (0.469) \\
\hline $\begin{array}{l}\text { Private sector } \\
\text { employees } \\
\text { employees }\end{array}$ & 0.031 & $(0.375)$ & -0.008 & $(0.256)$ & -0.029 & $(0.294)$ & 0.010 & $(0.404)$ & -0.073 & $(0.446)$ \\
\hline $\begin{array}{l}\text { Public sector } \\
\text { employees }\end{array}$ & 0.027 & $(0.380)$ & -0.002 & $(0.294)$ & -0.032 & $(0.319)$ & -0.070 & $(0.454)$ & -0.062 & (0.512) \\
\hline Bourgeoisie & 0.020 & $(0.378)$ & 0.018 & $(0.307)$ & -0.023 & $(0.321)$ & -0.014 & $(0.440)$ & -0.087 & $(0.485)$ \\
\hline Retired & 0.013 & $(0.359)$ & -0.062 & $(0.316)$ & -0.092 & $(0.354)$ & $-0.126^{\star}$ & $(0.428)$ & -0.080 & (0.493) \\
\hline Housewives & -0.009 & $(0.358)$ & -0.009 & $(0.293)$ & -0.031 & $(0.334)$ & $-0.096^{*}$ & $(0.441)$ & -0.066 & (0.511) \\
\hline Unemployed & 0.062 & $(0.432)$ & 0.016 & $(0.303)$ & -0.026 & $(0.344)$ & -0.024 & (0.469) & -0.063 & $(0.558)$ \\
\hline Students & 0.032 & $(0.507)$ & -0.030 & $(0.333)$ & -0.052 & $(0.475)$ & -0.086 & $(0.657)$ & $-0.130^{\star}$ & $(0.700)$ \\
\hline $\begin{array}{l}\text { Church } \\
\text { attendance }\end{array}$ & -0.058 & $(0.051)$ & $-0.111^{\star * \star}$ & $(0.042)$ & $-0.072^{* *}$ & $(0.048)$ & -0.049 & $(0.063)$ & $-0.140^{\star \star *}$ & $(0.068)$ \\
\hline North-East & -0.027 & $(0.288)$ & $-0.103^{\star \star}$ & $(0.250)$ & $-0.114^{\star *}$ & $(0.251)$ & -0.017 & $(0.368)$ & 0.053 & $(0.330)$ \\
\hline Red Zone & -0.044 & $(0.301)$ & $-0.104^{\star \star}$ & $(0.262)$ & $-0.082^{*}$ & $(0.276)$ & 0.025 & $(0.377)$ & 0.034 & $(0.365)$ \\
\hline Centre-South & -0.070 & $(0.323)$ & $-0.075^{\star}$ & $(0.276)$ & -0.005 & $(0.293)$ & 0.017 & $(0.396)$ & 0.065 & $(0.410)$ \\
\hline South & -0.038 & $(0.294)$ & -0.060 & $(0.253)$ & 0.009 & $(0.280)$ & 0.099 & $(0.387)$ & $0.126^{\star *}$ & (0.369) \\
\hline $\begin{array}{l}\text { Political } \\
\text { interest }\end{array}$ & -0.003 & $(0.090)$ & 0.031 & $(0.075)$ & $0.114^{\star * *}$ & $(0.100)$ & 0.029 & $(0.126)$ & 0.012 & $(0.145)$ \\
\hline Centre & -0.065 & $(0.228)$ & -0.046 & $(0.177)$ & 0.026 & $(0.207)$ & -0.000 & $(0.274)$ & 0.059 & $(0.277)$ \\
\hline Right & $-0.216^{\star \star \star}$ & $(0.202)$ & $-0.153^{\star \star \star}$ & $(0.167)$ & $-0.093^{\star \star}$ & $(0.194)$ & -0.025 & $(0.233)$ & 0.031 & (0.259) \\
\hline Not Self-Placed & -0.036 & $(0.223)$ & -0.026 & $(0.203)$ & 0.025 & $(0.270)$ & $0.172^{* \star *}$ & $(0.378)$ & $0.144^{* *}$ & (0.598) \\
\hline $\mathbf{N}$ & \multicolumn{2}{|c|}{1387} & \multicolumn{2}{|c|}{2901} & \multicolumn{2}{|c|}{2482} & \multicolumn{2}{|c|}{2018} & \multicolumn{2}{|c|}{1482} \\
\hline R-squared & \multicolumn{2}{|c|}{0.116} & \multicolumn{2}{|c|}{0.096} & \multicolumn{2}{|c|}{0.095} & \multicolumn{2}{|c|}{0.116} & \multicolumn{2}{|c|}{0.205} \\
\hline AIC & \multicolumn{2}{|c|}{6270.8} & \multicolumn{2}{|c|}{14133.3} & \multicolumn{2}{|c|}{12409.8} & \multicolumn{2}{|c|}{10335.7} & \multicolumn{2}{|c|}{7466.2} \\
\hline BIC & \multicolumn{2}{|c|}{6406.9} & \multicolumn{2}{|c|}{14288.6} & \multicolumn{2}{|c|}{12561.1} & \multicolumn{2}{|c|}{10481.6} & \multicolumn{2}{|c|}{7604.1} \\
\hline
\end{tabular}


Table 6: Goodness-of-fit of OLS regressions for each panel wave, base model and full model compared

\begin{tabular}{|l|l|c|c|c|c|}
\hline & & $\mathbf{2 0 1 2 - 0 4}$ & $\mathbf{2 0 1 2 - 1 0}$ & $\mathbf{2 0 1 3 - 0 2}$ & $\mathbf{2 0 1 3 - 0 3}$ \\
\hline \multirow{5}{*}{ Base model } & R-squared & 0.096 & 0.095 & 0.116 & 0.205 \\
\cline { 2 - 6 } & AIC & 14133.3 & 12409.8 & 10335.7 & 7466.2 \\
\cline { 2 - 6 } & BIC & 14288.6 & 12561.1 & 10481.6 & 7604.1 \\
\hline \multirow{3}{*}{ Full model* } & R-squared & 0.173 & 0.163 & 0.207 & 0.292 \\
\cline { 2 - 6 } & AIC & 5301.7 & 5479.7 & 5446.4 & 4414.8 \\
\cline { 2 - 6 } & BIC & 5446.4 & 5624.5 & 5591.2 & 4553.8 \\
\hline
\end{tabular}

Source: Author.

\section{Concluding Remarks}

The purpose of the present article was to investigate what stands behind the success of the M5S in the 2013 Italian general election. Moving from the electoral results of the M5S, I wondered if the profile of the M5S supporters had changed over time. The results show that the M5S has a cross-cutting profile both from a political and sociological standpoint, with some changes over time. In particular, while in November 2011 the percentage of the leftist supporters of the M5S was much more than the percentage of the right-wing supporters, this gap decreases over time and in March 2013 left and right show more or less the same percentage among M5S supporters. Moreover, the percentage of those who do not place themselves along the left-right scale increases significantly over time. In addition, it can be noticed that over time the relative share of M5S supporters from the Centre-South increases, whereas those from the Red Zone and, to some extent, those from the North decrease.

Furthermore, I was interested to discover which factors had a greater impact on the propensity to vote for the M5S and how these factors had changed over time. I expected that young age was an important predictor of the Ptv for the M5S and I hypothesized that the impact of some variables (in particular political self-placement) could change over time.

The findings are interesting and, to a certain extent, surprising. Indeed, according to several surveys (some of them reported in the first paragraph) the youngest and most educated people voted more for the M5S than for the main parties. This point has been stressed also by other empirical studies (Maraffi et al. 2013). Contrary to expectation, the analysis shows that young age (18-25) is not an explanatory factor of the vote for the M5S when other individual characteristics are taken into account. Furthermore, the level of education and political involvement are not predictors of the propensity to vote for the M5S. Not even geography matters, if we do not consider that living in the South increases the probability of voting for the M5S compared to living in the North-West. In order to explain the M5S support, other variables are more important, namely attitudes towards the Euro, one media-related variable (the use of Internet as the main source of political information), church attendance, the cultural dimension based on the Libertarian-Authoritarian distinc- 
tion and the rejection of political dimension based on left and right. Furthermore, the probability of voting for the M5S decreases consistently among housewives and the retired in comparison with manual workers. On the contrary, there are no significant differences between manual workers and other occupational categories in terms of the propensity to vote for the M5S.

Factors explaining the propensity to vote for the M5S and their relative importance have changed over time. In particular, as I expected, this is true for political self-placement and also for territorial variables and, to some extent, for social-class-related variables. From November 2011 to March 2013, there was a sharp change with regard to political self-placement: Being leftist no longer increases the probability of voting for the M5S in comparison with those who are right-wing supporters, while rejecting the left-right dimension increases the propensity to vote for the M5S. In other words, the M5S originally collects consensus especially on the left of the political space, but this ideological characterization is lost over time. This point is consistent with the results of other research (Biorcio 2013; Bordignon and Ceccarini 2013b) which shows the cross-cutting profile of the M5S voters in ideological terms and for most of them the rejection of the left-right dimension.

Moreover, from April 2012 to March 2013 the relationship between geography and voting for the M5S has been reversed: Living in the North-West no longer increases the probability of voting for the M5S compared to living in the South, but the reverse is true. With regard to social-class-related variables, in the first three waves (from November 2011 to October 2012) employment/non-employment status does not have any influence on the Ptv for the M5S. Afterwards, being retired or housewife affects negatively the Ptv for the M5S in comparison with manual workers.

In conclusion, using the Internet as the main source of political information, having negative attitudes towards the Euro, rejecting the left-right dimension, not being a religious practitioner and being open-minded with regard to moral topics increase the probability of voting for the M5S. It has to be pointed out that for M5S voters the European Union is a matter of political distinction, maybe another axis of political polarization alongside the cultural axis and the left-right axis (and the latter is not useful in order to explain the vote for the M5S). In this regard, other studies have pointed out the negative attitudes of M5S voters towards the European Union (Biorcio 2013).

Furthermore, the over-representation of M5S voters among the youngest age groups stressed by survey data could suggest that behind the electoral success of the M5S there was a generational divide, as hypothesized also by some empirical studies (Maraffi et al. 2013). However, our results show how behind the electoral success of the M5S there is not a generational divide but a technological divide, as suggested by De Sio (2013). The latter shows how M5S voters are over-represented among those who inform themselves mainly through the Internet, regardless of their age. Finally, the panel regression analysis carried out in this article proves the strong relationship between the use of the Internet as the main source of political information and the propensity to vote for the M5S. 


\section{Notes:}

1. These are estimates made with precinct level data using the Goodman model.

2. In 2008 the IdV was part of the Veltroni coalition and in 2013 joined Civil Revolution.

3. The multilevel regression command that I have applied in Stata 12 is $x$ treg, re that fits cross-sectional time-series random-effects regression model by using the GLS estimator.

4. CATI interviews.

5. CATI and CAMI interviews.

6. These variables are gender, age, education, profession, religion (church attendance), and geographical area of residence.

7. In this case, I have created a dummy variable: 1 means "Internet" and 0 means "all other media".

8. Level of political interest of respondent measured on a four-point scale.

9. In this case, I have run a factor analysis (PCF) including variables linked to issues on moral topics (e.g. opinion on civil partnership, on gay marriage, on euthanasia, on abortion) and variables showing attitudes towards other issues. The result was two different factor components. Therefore, an additive index linked to the first factor component has been created as an indicator of libertarian values.

10. In particular, opinion on the statement "Italy should leave the Euro system". The position of the voter on this issue is determined on a four point-scale with scores corresponding to "I strongly agree", "I quite agree", "I little agree", "I don't agree at all".

11. The political self-placement of the respondent is measured on a scale from 0 to 10 , where 0 means "left" and 10 means "right".

12. In order to specify the panel variable in Stata 12 I have applied the xtset command.

13. With regard to age, I have created a dummy identifying as young people all those who are 18-25 years old at the time of the 2013 general election.

14. With regard to the political self-placement of respondents, I have recoded the left-right scale by creating four dummies identifying "the left", "the centre", "the right", "those not self-placed".

15. In the pooled analysis, I have considered only the panel study because in the 2011 cross-section survey there were not some important questions (i.e. issues linked to the Euro and to some moral topics, the question on mass media as the source of political information).

\section{Sources:}

Baltagi, Badi H. 2008. Econometric Analysis of Panel Data. 4th edition. Chichester: John Wiley \& Sons.

Berelson, Bernard et al. 1954. Voting. A study of opinion formation in a presidential campaign. Chicago: University of Chicago Press.

Biorcio, Roberto. 2013. "La sfida del Movimento 5 stelle.” In: Voto amaro. Disincanto e crisi economica nelle elezioni del 2013. Ed. ITANES. Bologna: Il Mulino, 107-119.

Biorcio, Roberto and Natale, Paolo. 2013. Politica a 5 Stelle. Idee, storia e strategie del movimento di Grillo. Milano: Feltrinelli.

Bordignon, Fabio and Ceccarini, Luigi. 2012. "5 Stelle, un autobus in MoVimento." Il Mulino 5, 808-816.

Bordignon, Fabio and Ceccarini, Luigi. 2013a. "Five Stars and a Cricket. Beppe Grillo Shakes Italian Politics." South European Society and Politics, 1-23.

Bordignon, Fabio and Ceccarini, Luigi. 2013b. "Tsunami a 5 stelle.” In: Un Salto nel Voto. Ed. Ilvo Diamanti. Rome: Laterza, 60-71.

Bosco, Anna and McDonnell, Duncan. 2012. "Introduzione. Da Berlusconi a Monti: default dei partiti?" In: Politica in Italia. I fatti dell'anno e le interpretazioni. Edizione 2012. Eds. Anna Bosco and Duncan McDonnell. Bologna: Il Mulino, 43-61. 
Campbell, Angus et al. 1960. The American Voter. New York, London: Wiley.

Cataldi, Matteo and Emanuele, Vincenzo. 2013. "An electoral tsunami hits Italy: 50 provinces washed away from PD and PDL." In: The Italian General Election of 2013. A dangerous stalemate? Eds. Lorenzo De Sio et al. Rome: CISE: 49-50.

Ceccarini, Luigi et al. 2012. "Fine di un ciclo: la destrutturazione del sistema partitico italiano." In: Politica in Italia. I fatti dell'anno e le interpretazioni. Edizione 2012. Eds. Anna Bosco and Duncan McDonnell. Bologna: Il Mulino, 63-82.

Converse, Philip E. 1975. "Public Opinion and Voting Behavior". In: Handbook of Political Science, Vol. 4. Eds. Fred -I. Greenstein and Nelson W. Polsby. Reading, Mass.: Addison-Wesley, 75-169.

Corbetta, Piergiorgio. 2013. "Conclusioni. Un web-populismo dal destino incerto". In: Il partito di Grillo. Eds. Piergiorgio Corbetta and Elisabetta Gualmini. Bologna: Il Mulino, 197-214.

Corbetta, Piergiorgio and Gualmini, Elisabetta, eds. 2013. Il partito di Grillo. Bologna: Il Mulino.

Dalton, Russel J. and Wattenberg, Martin P. 1993. "The Not Simple Act of Voting”. In: Political Science: The State of the Discipline. 2nd ed. Ed. Ada Finifter. Washington, DC: American Political Science Association, 193-218.

De Sio, Lorenzo. 2013. “A ‘media divide' in the vote of February 25?” In: The Italian General Election of 2013. A dangerous stalemate? Eds. Lorenzo De Sio et al. Rome: CISE, 69-71.

De Sio, Lorenzo et al., eds. 2013. The Italian General Election of 2013. A dangerous stalemate? Rome: CISE.

Downs, Anthony. 1957. An Economic Theory of Democracy. New York: Harper.

van der Eijk, Cees and Franklin, Mark N., eds. 1996. Choosing Europe? The European Electorate and National Politics in the Face of the Union. Ann Arbor, MI: The University of Michigan Press.

van der Eijk, Cees et al. 2006. "Rethinking the Dependent Variable in Voting Behavior: On the Measurement and Analysis of Electoral Utilities." Electoral Studies 25, No. 3, 424-447.

Flanagan, Scott C. 1982. "Changing Values in Advanced Industrial Societies." Comparative Political Studies 14, No. 4, 403-444.

Kuechler, Manfred. 1991. "Issues and Voting in the European Elections 1989." European Journal of Political Research 19, No. 1, 81-103.

Lazarsfeld, Paul F. et al. 1944. The People's Choice. How the Voter Makes up his Mind in a Presidential Campaign. New York: Columbia University Press.

Legnante, Guido and Baldassarri, Delia. 2010. "Campagne elettorali e mediazione sociale: esposizione ai media e relazioni interpersonali". In: Votare in Italia: 1968-2008. Dall'appartenenza alla scelta. Eds. Paolo Bellucci and Paolo Segatti. Bologna: Il Mulino, 249-288.

Lipset, Seymour M. and Rokkan, Stein. 1967. "Cleavage Structures, Party Systems and Voter Alignments: An Introduction.” In: Party Systems and Voter Alignments: Cross-National Perspectives. Eds. Seymour M. Lipset and Stein Rokkan. New York: The Free Press, 1-64.

Maraffi, Marco et al. 2013. "Le basi sociali del voto." In: Voto amaro. Disincanto e crisi economica nelle elezioni del 2013. Ed. ITANES. Bologna: Il Mulino, 57-70.

Rabe-Hesketh, Sophia and Skrondal, Anders. 2008. Multilevel and Longitudinal Modeling Using Stata. 2nd ed. College Station, TX: Stata Press.

Sani, Giacomo and Legnante, Guido. 2001. "La comunicazione politica in televisione (1998-1999).” In: Mass media ed elezioni. Ed. Giacomo Sani. Bologna: Il Mulino, 127-158.

Smith, Eric RAN. 1989. The Unchanging American Voter. Berkeley and Los Angeles: University of California Press.

Verbeke, Geert and Molenberghs, Geert. 2000. Linear Mixed Models for Longitudinal Data. New York: Springer. 